\title{
Activity-Dependent Repression of Cbln1 Expression: Mechanism for Developmental and Homeostatic Regulation of Synapses in the Cerebellum
}

\author{
Takatoshi Iijima, Kyoichi Emi, and Michisuke Yuzaki \\ Department of Physiology, School of Medicine, Keio University, Tokyo 160-8582, Japan
}

Cbln1, which belongs to the $\mathrm{Clq} /$ tumor necrosis factor superfamily, is released from cerebellar granule cells and plays a crucial role in forming and maintaining excitatory synapses between parallel fibers (PFs; axons of granule cells) and Purkinje cells not only during development but also in the adult cerebellum. Although neuronal activity is known to cause morphological changes at synapses, how Cbln1 signaling is affected by neuronal activity remains unclear. Here, we show that chronic stimulation of neuronal activity by elevating extracellular $\mathrm{K}^{+}$levels or by adding kainate decreased the expression of $c b \ln 1 \mathrm{mRNA}$ within several hours in mature granule cells in a manner dependent on L-type voltage-dependent $\mathrm{Ca}^{2+}$ channels and calcineurin. Chronic activity also reduced Cbln 1 protein levels within a few days, during which time the number of excitatory synapses on Purkinje cell dendrites was reduced; this activity-induced reduction of synapses was prevented by the addition of exogenous Cbln 1 to the culture medium. Therefore, the activity-dependent downregulation of $c b \ln 1$ may serve as a new presynaptic mechanism by which PF-Purkinje cell synapses adapt to chronically elevated activity, thereby maintaining homeostasis. In addition, the expression of $c b \ln 1 \mathrm{mRNA}$ was prevented when immature granule cells were maintained in high- $\mathrm{K}^{+}$medium. Since immature granule cells are chronically depolarized before migrating to the internal granule layer, this depolarization-dependent regulation of $c b l n 1$ mRNA expression may also serve as a developmental switch to facilitate PF synapse formation in mature granule cells in the internal granule layer.

\section{Introduction}

Cbln1 is one of the most recently identified proteins involved in synapse formation in the CNS. Cbln 1 belongs to a Cbln subfamily (consisting of Cbln1-Cbln4) of the C1q/tumor necrosis factor (TNF) superfamily (Yuzaki, 2008). In the cerebellum, Cbln1 is released from granule cells and plays a crucial role in forming excitatory synapses between parallel fibers (PFs; axons of granule cells) and Purkinje cells during development; the number of PFPurkinje cell synapses decreased by $80 \%$ in mice with a disrupted $c b \ln 1$ gene $\left(c b \ln 1^{-1-}\right)$ (Hirai et al., 2005). Interestingly, the single application of recombinant Cbln1 rapidly, but transiently, restored PF synapses in mature $c b \ln 1^{-1-}$ Purkinje cells both in vitro and in vivo (Ito-Ishida et al., 2008). Therefore, Cbln1 is a unique synapse organizer that is required not only for the normal development of PF-Purkinje cell synapses but also for their stabilization in the mature cerebellum.

Since Cbln1 remains highly expressed in adult cerebellum (Miura et al., 2006), it would inhibit morphological changes at PF-

\footnotetext{
Received Sept. 18, 2008; revised March 3, 2009; accepted March 23, 2009.

This work was supported by a Grant-in-Aid from the Ministry of Education, Culture, Sports, Science, and Technology (M.Y.), Sankyo Foundation of Life Science (M.Y.), Takeda Science Foundation (M.Y.), a Grant-in-Aid for the 21st Century Center of Excellence program at Keio University (T.I.), and Grant-in-Aid for Young Scientist (B) from the Japan Society for the Promotion of Science (T.I.). We thank J. Motohashi, K. Yoshikawa, and S. Narumi for their technical support. We also thank Drs. K. Matsuda, A. Ito-Ishida, and T. Kondo for valuable discussions.

Correspondence should be addressed to Michisuke Yuzaki, Department of Physiology, School of Medicine, Keio University, 35 Shinanomachi, Shinjuku-ku, Tokyo 160-8582, Japan. E-mail: myuzaki@a5.keio.jp.

D0I:10.1523/JNEUROSCI.4473-08.2009

Copyright $\odot 2009$ Society for Neuroscience $\quad$ 0270-6474/09/295425-10\$15.00/0
}

Purkinje cell synapses. Indeed, unlike in $c b l n 1^{-1-}$ cerebellum, application of exogenous Cbln1 failed to induce any synaptogenesis in wild-type cerebellum (Ito-Ishida et al., 2008). Nevertheless, changes in neuronal activity reportedly induce considerable structural changes at $\mathrm{PF}$ synapses in adult cerebellum in vivo (Black et al., 1990; Cesa et al., 2007). Thus, we hypothesized that neuronal activities may modulate Cbln1 signaling pathways to allow structural changes to occur at mature PF synapses. To test this hypothesis, we examined how $c b \ln 1 \mathrm{mRNA}$ levels were regulated by the activity of cultured cerebellar granule cells. Here, we show that sustained membrane depolarization, which activated L-type voltage-gated $\mathrm{Ca}^{2+}$ channels (L-VGCC) and calcineurin (CaN), inhibited cbln1 mRNA transcription within several hours in mature granule cells in culture. Furthermore, chronic stimulation of neuronal activity by elevating extracellular $\mathrm{K}^{+}$levels for several days significantly reduced Cbln1 protein levels and the number of excitatory synapses in mature wild-type cerebellar cultures. Therefore, the activity-dependent downregulation of $c b \ln 1$ may serve as a new presynaptic mechanism by which PF-Purkinje cell synapses adapt to chronically elevated activity, thereby maintaining homeostasis. In addition, the expression of cbln1 mRNA was prevented when immature granule cells were maintained in high $\mathrm{K}^{+}$medium. Since granule cells are continuously depolarized in the external granule layer (EGL) and then become repolarized after migration into the internal granule layer (IGL) (Rossi et al., 1998), this depolarization-dependent regulation of $c b \ln 1 \mathrm{mRNA}$ expression may also serve as a developmental switch for granule cells in the IGL to initiate PF synapse formation. 


\section{Materials and Methods}

Primary cell cultures. Cerebellar granule cells were cultured from ICR mice on postnatal day 5 (P5)-P7, as described previously (Kurschner and Yuzaki, 1999). Cells were maintained in Neurobasal medium (Invitrogen) containing $5 \mathrm{~mm} \mathrm{KCl}$ and $\mathrm{B} 27$ (Invitrogen) in $5 \% \mathrm{CO}_{2}$ at $37^{\circ} \mathrm{C}$ and used at $14 \mathrm{~d}$ in vitro (DIV). "Mixed" cerebellar cultures were prepared from day-of-birth ICR mice, as described previously (ItoIshida et al., 2008). Cells were plated at a density of $3 \times 10^{3}$ cells on glass coverslips (diameter, $13.5 \mathrm{~mm}$ ), maintained in DMEM/F12 (Invitrogen) containing $0.1 \%$ fetal calf serum in $5 \% \mathrm{CO}_{2}$ at $37^{\circ} \mathrm{C}$, and used at 18-20 DIV. All procedures related to animal care and treatment were approved by the Animal Resource Committee of the School of Medicine, Keio University.

Kainate-induced seizure. Adult C57BL/6J mice ( $>8$ weeks old) were intraperitoneally injected with PBS or kainate (20 $\mu \mathrm{g} / \mathrm{g}$ in PBS). Cerebella were harvested from mice $4 \mathrm{~h}$ after the injection of PBS or kainate and subjected to the following reverse transcription-PCR (RT-PCR) analyses; mice that did not develop generalized seizures within $30 \mathrm{~min}$ after the injection of kainate were excluded from the analysis.

RNA isolation and quantitative RT-PCR. Total RNA was isolated with Trizol reagent (Invitrogen) and treated with DNase I (Invitrogen). The cDNAs were synthesized from $1 \mu \mathrm{g}$ of total RNA using an oligo-dT primer and Superscript III RNase H-reverse transcriptase (Invitrogen) at $50^{\circ} \mathrm{C}$ for $60 \mathrm{~min}$. Semiquantitative PCR was performed as described previously (Miura et al., 2006) by coamplification of glyceraldehyde phosphate dehydrogenase (GAPDH) mRNA, which is expressed ubiquitously and constitutively, using a second set of primers in the same PCR tube. To assure the linearity of our RT-PCR assay, we performed preliminary experiments for each cDNA to be analyzed by sampling $5 \mu \mathrm{l}$ aliquots at every fourth cycle of the reaction. PCR was performed with TaqDNA polymerase (Qiagen) using specific sets of primers (Table 1). After agarose gel electrophoresis, the fragments were detected by staining with ethidium bromide and the band intensities were quantified using an image analyzer (FAS-III; Toyobo) and ImageGauge software (version 3.45; Fujifilm). The absence of genomic DNA contamination was confirmed by performing PCR with an equivalent amount of total RNA but without reverse transcriptase. All PCR assays were performed using duplicate samples in more than three independent cultures prepared from separate groups of animals.

Immunoblot analysis. Cultured cerebellar granule cells were lysed with buffer $(10 \mathrm{~mm}$ Tris- $\mathrm{HCl}, \mathrm{pH}$ 8.0, $100 \mathrm{~mm} \mathrm{NaCl}, 1 \mathrm{~mm}$ EDTA, $1 \%$ Triton X-100) containing $0.1 \%$ SDS and a protease inhibitor mixture mix (Roche Applied Science), and the soluble fractions were analyzed by immunoblotting with anti-Cbln1 or anti-Cbln3 antibody (rabbit; 1:250), which were kindly provided by Dr. Masahiko Watanabe (Hokkaido University, Sapporo, Japan) (Iijima et al., 2007; Miura et al., 2009). Horseradish peroxidase-conjugated secondary antibody and the enhanced chemiluminescence kit (both from GE Healthcare) were used for these analyses. The band intensities were quantified using ImageGauge software (version 3.45; Fujifilm).

Preparation of recombinant Cbln1. Hemagglutinin (HA)-tagged Cbln1 was expressed in HEK293 tSA cells (a kind gift from Dr. R. Horn, Thomas Jefferson University Medical School, Philadelphia, PA) as described previously (Ito-Ishida et al., 2008). Five hours after transfection, the culture medium was substituted with a cerebellar culture medium. The medium

B
Table 1. Sequences and PCR cycles for primer sets used in the RT-PCR analyses

\begin{tabular}{|c|c|c|}
\hline Primer & Sequence $\left(5^{\prime}-3^{\prime}\right)$ & Cycles $(n)$ \\
\hline$c b \ln 1-F$ & 5'-CCA GGT ACT AGT GAA CAT CGG G-3' & 25 \\
\hline cbln1-R & 5'-TCA GAG GGG AAA CAC GAG GAA TC-3' & \\
\hline cbln3-F & 5'-TTT GAT CGG ACC TCG GGC TGC-3' & 30 \\
\hline$c b \ln 3-R$ & 5'-TCA GAG TGG GAA GAT GAG GAA G-3' & \\
\hline $\mathrm{NR} 2 \mathrm{C}-\mathrm{F}$ & 5'-CGT TCT GCT GGG GGA CTG TCT G-3' & 30 \\
\hline NR2C-R & 5'-TCA CAC TTC TGA TTC CAG GCT G-3' & \\
\hline GABA $\alpha 6-\mathrm{F}$ & $5^{\prime}-\mathrm{GCA}$ GGC ACA AAC TGC AGC CAC GC-3' & 30 \\
\hline GABA $\alpha 6-R$ & 5'-CTA CTC AAC AGT ACT GCT CAC T-3' & \\
\hline$c-f o s-F$ & $5^{\prime}$-TCC ACC CCA GAG TCT GAG GAG G-3' & 25 \\
\hline$c-f 0 s-R$ & $5^{\prime}$-TCA CAG GGC CAG CAG CGT GGG TG-3' & \\
\hline BDNF-F & $5^{\prime}$-GGA CAT GTC TGG CGG GAC GGT C-3' & 30 \\
\hline BDNF-R & 5'-CTA TCT TCC CCT TTT AAT GGT CAG-3' & \\
\hline GAPDH-F & $5^{\prime}$-TGT TGC CAT CAA TGA CC-3' & 25 \\
\hline GAPDH-R & $5^{\prime}$-TCT CAT GGT TCA CAC CCA-3' & \\
\hline
\end{tabular}

$F$, Forward; $R$, reverse.
C

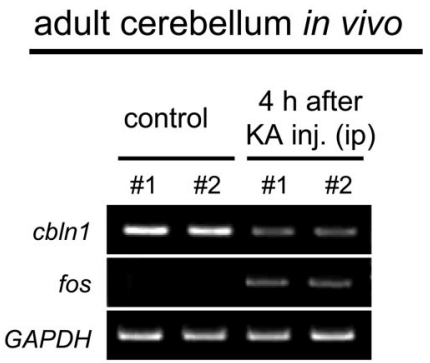

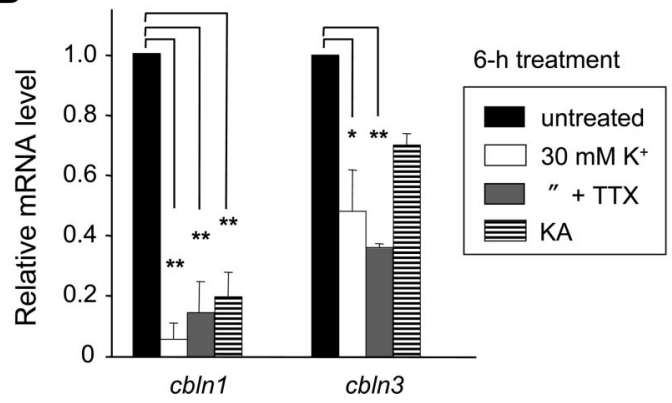

Figure 1. Downregulation of cbln $1 \mathrm{mRNA}$ by increased neuronal activities in vitro and in vivo. $A$, Activity-dependent changes in expression of $c$ ln 1 and cbln 3 mRNAs in mature granule cells. Granule cells maintained in $5 \mathrm{~mm} \mathrm{~K}^{+}$for 2 weeks were treated with for cbln1, cbln3, BDNF, and GAPDH were determined using semiquantitative PCR as described in Materials and Methods. $\boldsymbol{B}$ Quantitative analysis of the expression levels of $c b / n 1$ and $c b / n 3$ mRNAs. The band intensities of $c b / n 1$ or $c b / n 3$ RT-PCR products experiments. ${ }^{*} p<0.05,{ }^{* *} p<0.01$. C, Activity-dependent reduction in expression of cbln $1 \mathrm{mRNA}$ in mature cerebellum in vivo. Four hours after the intraperitoneal injection of kainate $(20 \mu \mathrm{g} / \mathrm{g})$, the expression levels of $c$ bln $1, c$-fos, and GAPDH mRNAs were determined by semiquantitative RT-PCR analysis in two 8-week-old C57BL/6J mice.

containing recombinant HA-Cbln1 secreted from transfected cells was harvested $24 \mathrm{~h}$ after transfection. To confirm the structural specificity of Cbln1, a mutant Cbln1 (dS-Cbln1), in which cysteine 34 and cysteine 38 were replaced with serines, was also prepared (Bao et al., 2005). The concentration of recombinant HA-Cbln1 or HA-dS-Cbln1 in the medium was quantified using an immunoblot analysis with purified $6 \times$ histidine-tagged HA-Cbln1 as the standard (Ito-Ishida et al., 2008).

Immunocytochemical analysis of neurons. Cultured cerebellar neurons were fixed with $4 \%$ paraformaldehyde in PBS for $20 \mathrm{~min}$ at room temperature and were further fixed with ice-cold 100\% methanol for $5 \mathrm{~min}$ on ice. The neurons were then permeabilized using PBS containing $0.3 \%$ Triton X-100 for $15 \mathrm{~min}$ at room temperature and incubated with blocking solution (10\% normal goat serum in PBS) for at least $30 \mathrm{~min}$ at room 

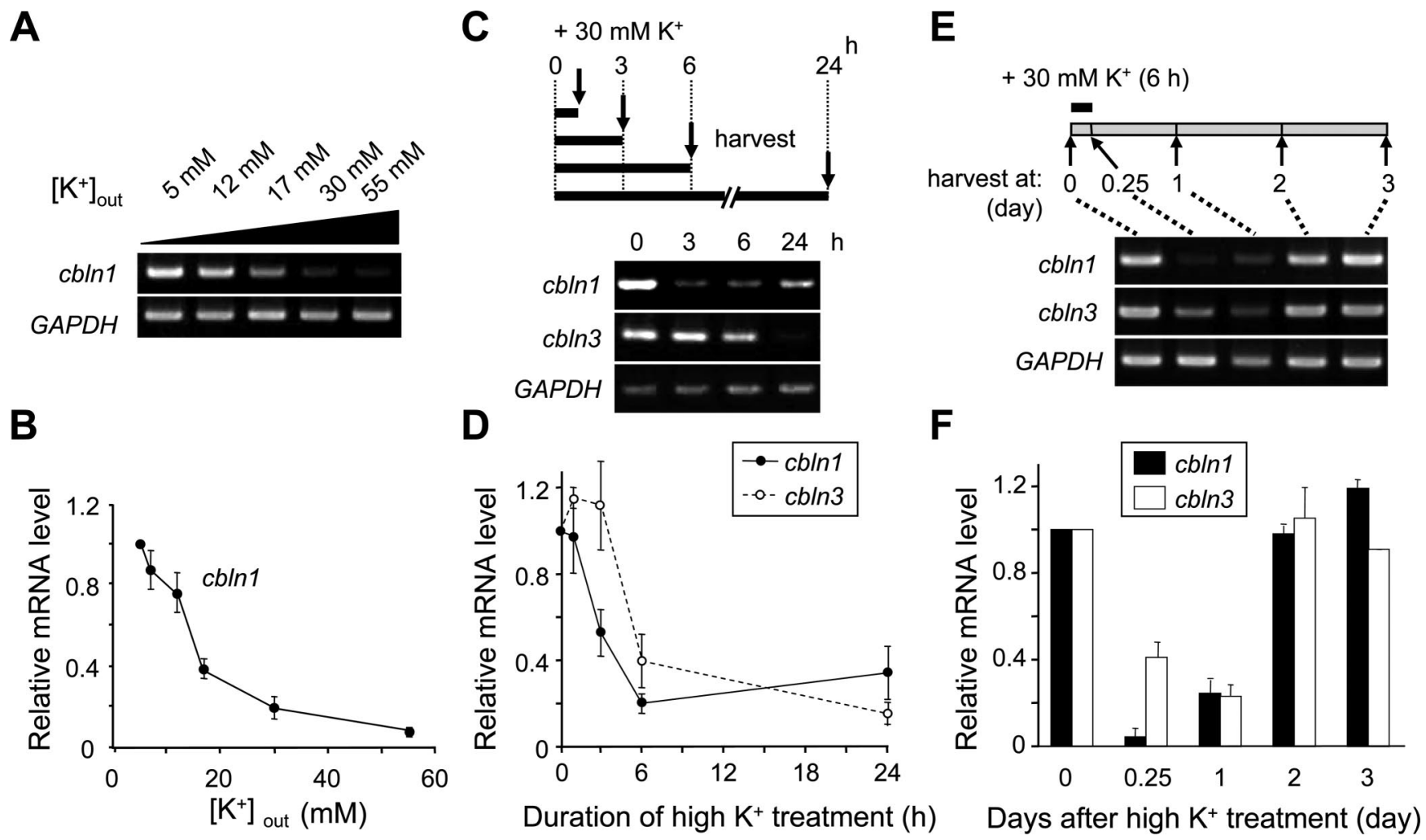

Figure 2. Depolarization conditions required to repress c $b / n 1 \mathrm{mRNA}$ expression. Cerebellar granule cells were maintained in $5 \mathrm{~mm} \mathrm{~K}^{+}$for 2 weeks and were treated with high $\mathrm{K}^{+}$under various conditions. $\boldsymbol{A}, \boldsymbol{B}$, Effects of extracellular $\mathrm{K}^{+}$concentrations. Granule cells were treated with media containing various concentrations of extracellular $\mathrm{K}^{+}$for $6 \mathrm{~h}$. Expression levels of $\mathrm{mRNAs}$ for c $b / \mathrm{n} 1$ and GAPDH were determined using semiquantitative PCR. The band intensities of the $c b / n 1$ transcripts were normalized to those of $G A P D H$, and the value of untreated $\left(5 \mathrm{~mm} \mathrm{~K}{ }^{+}\right)$granule cells was arbitrarily defined as $1.0(\boldsymbol{B}) . n=4$ independent experiments. $\boldsymbol{C}, \boldsymbol{D}$, Effects of duration of high $-\mathrm{K}^{+}$treatment. Granule cells were treated with $30 \mathrm{~mm} \mathrm{~K}^{+}$for $1,3,6$, or $24 \mathrm{~h}$. The expression levels of mRNAs for $c b / n 1, c b l n 3$, and GAPDH were determined at the end of each treatment using semiquantitative PCR. The band intensities of the $c b / n 1$ and $c b / n 3$ transcripts were normalized to those of $G A P D H$, and the value of untreated $(0 \mathrm{~h})$ granule cells was arbitrarily defined as $1.0(\boldsymbol{D}) . n=3$ independent experiments. $\boldsymbol{E}, \boldsymbol{F}$, Effects of elapsed time after high- $\mathrm{K}^{+}$treatment. Granule cells were treated with $30 \mathrm{~mm} \mathrm{~K}^{+}$for $6 \mathrm{~h}$ and the $c b / n 1, c b / n 3$, and GAPDH expression levels were analyzed at 0 and $6 \mathrm{~h}$ (at the end of the treatment) and 1, 2, or $3 \mathrm{~d}$ after treatment. The band intensities of the $c b / n 1$ and $c b / n 3$ transcripts were normalized to those of GAPDH, and the value of untreated $(0 \mathrm{~h})$ granule cells was arbitrarily defined as $1.0(\boldsymbol{F}) . n=3$ independent experiments.

temperature, followed by incubation with primary antibodies for $24 \mathrm{~h}$ at $4^{\circ} \mathrm{C}$ : anti-calbindin (mouse, 1:1000; Roche Applied Science), antivesicular glutamine transporter 1 (VGluT1; rabbit, 1:1000), anti-Cbln1 (rabbit; 1:200), anti-vesicular GABA transporter (VGAT; guinea pig, 1:2000), and anti- $\delta 2$ glutamate receptor (GluR $\delta 2$; rabbit, 1:1000; all kindly provided by Dr. Masahiko Watanabe) (Miyazaki et al., 2003). For visualization, appropriate secondary antibodies conjugated to Alexa 546 or 488 (goat; 1:2000) (Invitrogen) were used.

Fluorescence images were captured using a charge-coupled device camera (DP 70; Olympus) attached to a fluorescence microscope (BX60; Olympus). The original images were analyzed using ImageJ software (National Institutes of Health, Bethesda, MD). After subtracting the background level, the mean intensity of presynaptic markers within calbindin-positive dendritic areas distant from the soma by $>20 \mu \mathrm{m}$ was normalized to that of calbindin, as described previously (Ito-Ishida et al., 2008). The number of neurons was regarded as $n$ in the statistical analysis. Values from multiple areas within a neuron were averaged for each neuron. Immunohistochemical analyses for each group were performed using more than three independent cultures prepared from separate groups of animals.

Functional labeling of presynaptic terminals with FM4-64. Mixed cerebellar cultures maintained in normal $\mathrm{K}^{+}(5 \mathrm{mM})$ were treated with media containing normal $\mathrm{K}^{+}, 30 \mathrm{~mm} \mathrm{~K} \mathrm{~K}^{+}$or $30 \mathrm{~mm} \mathrm{~K}{ }^{+}$plus HA-Cbln1 (2 $\mu \mathrm{g} / \mathrm{ml})$ for $3 \mathrm{~d}$. The cells were incubated with the Tyrode's solution (20 mм HEPES, pH 7.2, 30 mм glucose, $129 \mathrm{~mm} \mathrm{NaCl}, 5 \mathrm{~mm} \mathrm{KCl}$ ) for $30 \mathrm{~min}$ at room temperature and treated for $5 \mathrm{~min}$ with the Tyrode's solution, to which $5 \mu \mathrm{M}$ FM4-64 (FM4-64FX; Invitrogen), $80 \mathrm{~mm} \mathrm{KCl}$, and $4 \mathrm{~mm}$ $\mathrm{CaCl}_{2}$ were added. Excess FM4-64FX dye was removed by rinsing cells with Tyrode's solution containing $100 \mu \mathrm{M}$ ADVASEP (CyDex Pharma- ceuticals), $4 \mathrm{~mm} \mathrm{MgCl} 2,1 \mu \mathrm{M}$ tetrodotoxin (TTX), $50 \mu \mathrm{M} \mathrm{D}-\mathrm{AP} 5$, and 50 $\mu \mathrm{M}$ CNQX. The FM4-64 fluorescence was reduced by reapplication of the Tyrode's solution containing $85 \mathrm{mM} \mathrm{KCl}$ and $4 \mathrm{mM} \mathrm{CaCl}_{2}$ for $5 \mathrm{~min}$, indicating that it reflected functional presynaptic sites. For quantification of presynaptic terminals on Purkinje cells, immediately after loading of the FM4-64 dye, cells were fixed with $0.25 \%$ glutaraldehyde and 3\% paraformaldehyde in PBS, and incubated with anti-calbindin (mouse, 1:1000; Roche Applied Science) in PBS containing 0.5\% saponin and $10 \%$ normal goat serum. After subtracting the background level, the mean intensity of the FM4-64 fluorescence within the calbindin-positive dendritic areas distant from the soma by $>20 \mu \mathrm{m}$ was measured using ImageJ software, as described above.

Statistical analysis. Data were analyzed using a Student's $t$ test. Data were represented as the mean \pm SEM. Statistical significance was assumed when $p<0.05$.

\section{Results}

Neuronal activity-dependent repression of $c b \ln 1$ and $c b \ln 3$ mRNA expression

To examine how the expression of Cbln 1 is modulated by external stimuli, we used cultured cerebellar granule cells prepared from P5-P7 mice and maintained for 2 weeks in media containing $5 \mathrm{mM} \mathrm{K}^{+}$. Semiquantitative RT-PCR analysis revealed that the expression of $c b \ln 1 \mathrm{mRNA}$ increased and reached a plateau at $\sim 1$ week in vitro, followed by the late expression of $c b l n 3$ mRNA (supplemental Fig. S1 A, B, available at www.jneurosci.org as supplemental material). In addition, at 2 weeks in vitro, the granule cells expressed high levels of NMDA receptor subunit NR2C and 


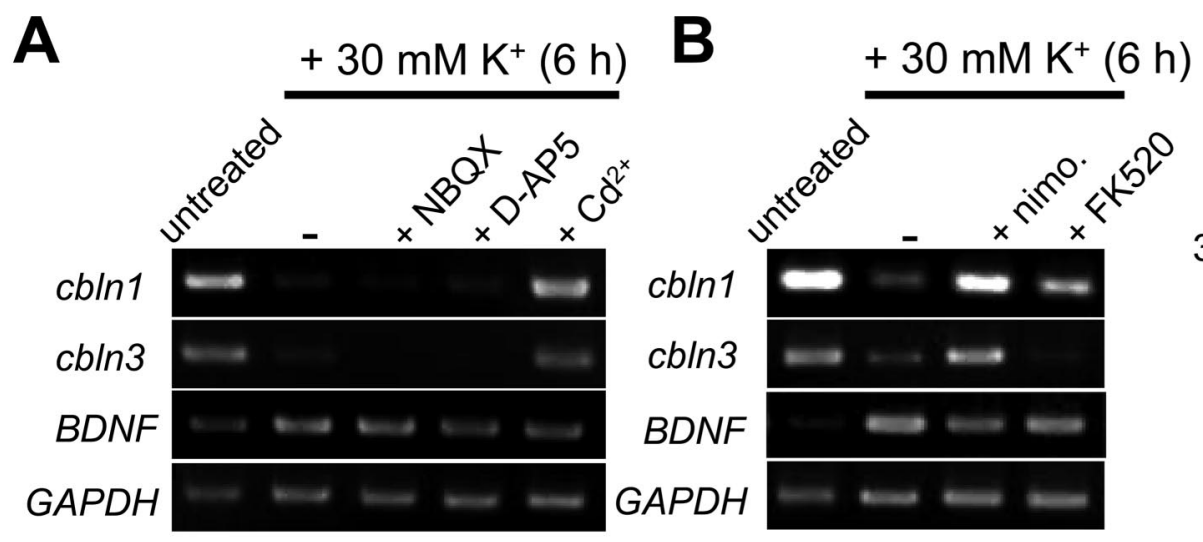

D
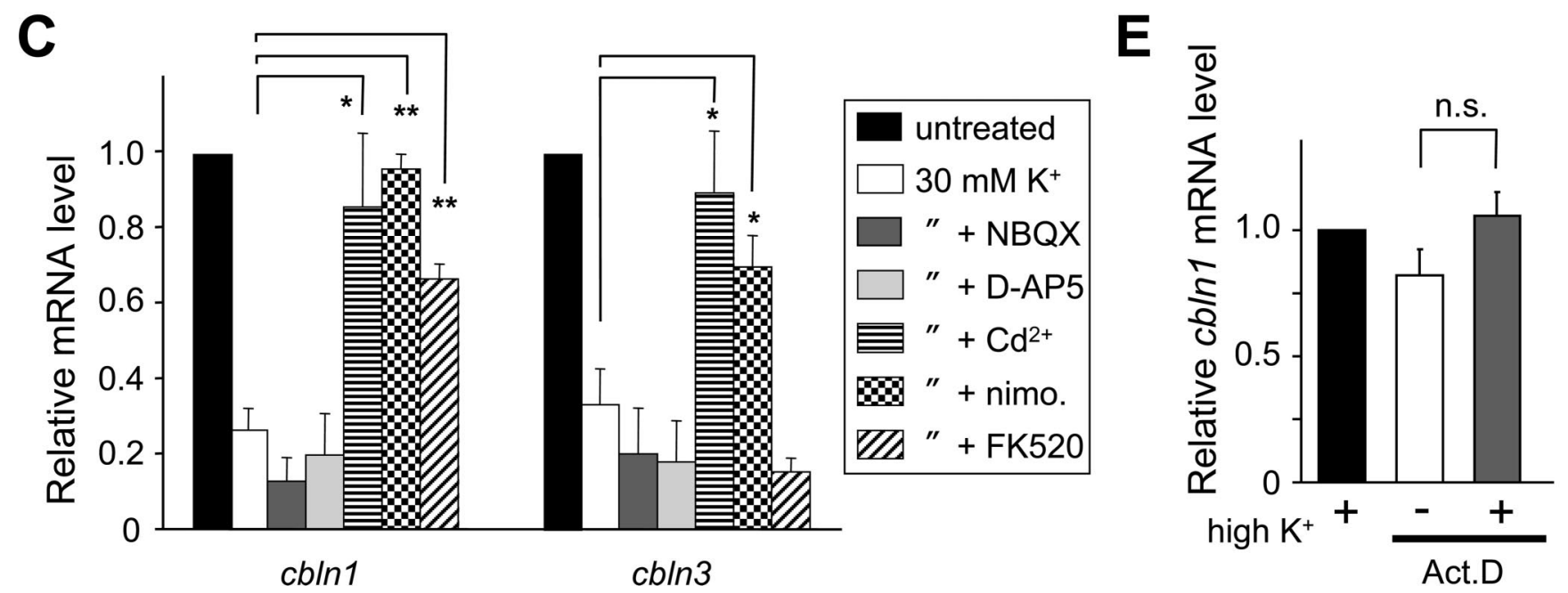

Figure 3. Effects of various inhibitors on high- $\mathrm{K}^{+}$-induced repression of cbln 1 and cbln $3 \mathrm{mRNAs}$. Cerebellar granule cells maintained in $5 \mathrm{~mm} \mathrm{~K}^{+}$for 2 weeks were treated with high $\mathrm{K}^{+}$for $6 \mathrm{~h}$ $(\boldsymbol{A}-\boldsymbol{C})$ or $3 \mathrm{~h}(\boldsymbol{D}, \boldsymbol{E})$ in the presence of various inhibitors. $\boldsymbol{A}$, Effects of an AMPA receptor blocker, NBQX $(25 \mu \mathrm{M})$, an NMDA receptor blocker, D-AP5 (100 $\mu \mathrm{M})$, and a general $\mathrm{Ca}{ }^{2+}$ channel inhibitor, $\mathrm{Cd}^{2+}(10 \mu \mathrm{M}) . \boldsymbol{B}$, Effects of an L-type voltage-gated $\mathrm{Ca}^{2+}$ channel blocker, nimodipine (nimo.; $\left.50 \mu \mathrm{m}\right)$, and a calcineurin inhibitor, FK520 $(0.5 \mu \mathrm{g} / \mathrm{ml})$. C, Quantitative analysis of the effects of inhibitors on the high- $\mathrm{K}^{+}$-induced repression of the expression of $c b \ln 1$ and $c b / n 3 \mathrm{mRNAs}$. The band intensities of $c b / n 1$ or $c b / n 3 \mathrm{RT}-\mathrm{PCR}$ products were normalized to those of GAPDH. The value of untreated granule cells was arbitrarily defined as 1.0. $n=4-10$ independent experiments. ${ }^{*} p<0.05,{ }^{* *} p<0.01 . D$, Effects of a transcription blocker, actinomycin D (Act.D; $40 \mu \mathrm{M}$ ).E, Quantitative analysis of the effects of actinomycin D on the high- $\mathrm{K}^{+}$-induced repression of the expression of c $b \ln 1 \mathrm{mRNA}$. The band intensities of $c b / n 1 \mathrm{RT}-\mathrm{PCR}$ products were normalized to those of GAPDH. The value of granule cells treated with high $\mathrm{K}^{+}$alone was arbitrarily defined as 1.0. $n=4$ independent experiments. n.s., No significant difference.

$\mathrm{GABA}_{\mathrm{A}}$ receptor $\alpha 6\left(G A B A_{A} \alpha 6\right)$ mRNAs (supplemental Fig. $\mathrm{S} 1 \mathrm{C}$, available at www.jneurosci.org as supplemental material). Such expression patterns are similar to those observed in granule cells in the IGL in vivo (Mellor et al., 1998; Nakanishi and Okazawa, 2006), indicating that the granule cells were well differentiated under this culture condition.

The expressions of various genes, such as brain-derived neurotrophic factor (BDNF), c-fos, and NMDA receptors, are regulated by neuronal activities, which can be mimicked by depolarization induced by high external $\mathrm{K}^{+}$levels (Bessho et al., 1993, 1994). Interestingly, when granule cells were treated with high $\mathrm{K}^{+}(30 \mathrm{~mm})$ for $6 \mathrm{~h}$, the expression levels of $c b \ln 1$ and $c b \ln 3$ mRNAs were significantly reduced (Fig. $1 A, B$ ). Similar effects were observed after treatment with high $\mathrm{K}^{+}$in the presence of TTX ( $2 \mu \mathrm{M})$, which blocks the depolarization-induced release of endogenous neurotransmitters (Fig. $1 A, B$ ). In addition, the application of kainate $(50 \mu \mathrm{M})$, a potent agonist for AMPA and kainate glutamate receptors, inhibited the expressions of $c b \ln 1$ and $c b \ln 3$ mRNAs in cultured granule cells (Fig. $1 A, B$ ). Furthermore, the intraperitoneal injection of kainate $(20 \mu \mathrm{g} / \mathrm{g})$ significantly reduced the expression level of $c b \ln 1 \mathrm{mRNA}$ in adult C57BL/6J mice in vivo (Fig. $1 C$ ). In contrast, the expressions of other genes, such as BDNF (Fig. $1 A$ ) and $c$-fos (Fig. 1C), were upregulated by high- $\mathrm{K}^{+}$or kainate treatment. These results indicated that sustained depolarization, induced by either high $\mathrm{K}^{+}$ or kainate, reduced the expressions of $c b \ln 1$ and $c b \ln 3$ mRNAs in mature granule cells.

\section{Prolonged but reversible repression of expression of $c b \ln 1$ and $c b \ln 3 m R N A s$}

To determine the precise conditions required to repress $c b \ln 1$ mRNA expression, we incubated granule cells in various concentrations of extracellular $\mathrm{K}^{+}$for $6 \mathrm{~h}$. The expression levels of $c b \ln 1$ mRNA decreased when the granule cells were depolarized to a greater extent using higher concentrations of $\mathrm{K}^{+}$, but the effect was almost saturated at $55 \mathrm{mM} \mathrm{K}^{+}$(Fig. $2 A, B$ ). Thus, the repression of $c b \ln 1$ mRNA expression is likely mediated by some membrane potential-gated mechanisms.

The expression of $c b \ln 1$ and $c b \ln 3$ mRNAs was also dependent on the duration of high- $\mathrm{K}^{+}$treatment. The inhibitory effect of 30 $\mathrm{mM} \mathrm{K}^{+}$, which was expected to depolarize neurons to approximately $-43 \mathrm{mV}$ (according to the Nernst equation, assuming an intracellular $\mathrm{K}^{+}$level of $150 \mathrm{mM}$ at $37^{\circ} \mathrm{C}$ ), on $c b \ln 1$ or $c b \ln 3$ mRNA expression became evident after incubation for 3 or $6 \mathrm{~h}$, respectively (Fig. $2 C, D$ ). In contrast, when granule cells were treated with $30 \mathrm{mM} \mathrm{K}^{+}$for $30 \mathrm{~min}$, the $c b \ln 1 \mathrm{mRNA}$ levels did not 
A

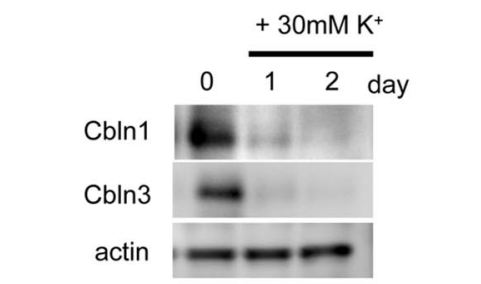

B

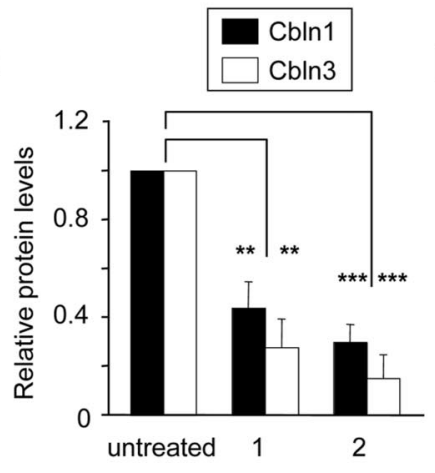

Duration of high $\mathrm{K}^{+}$treatment (day)
C

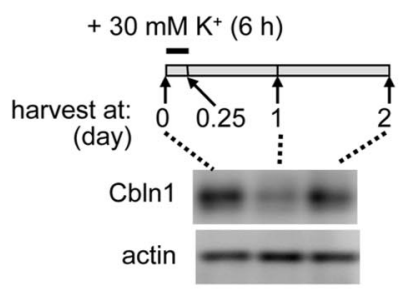

D

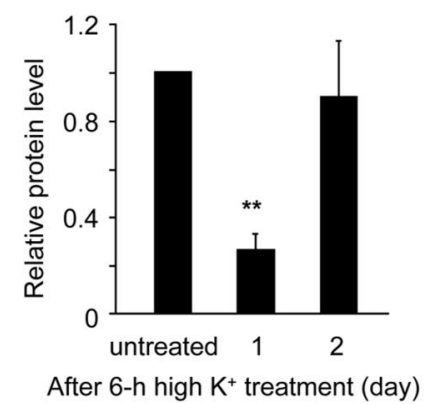

E
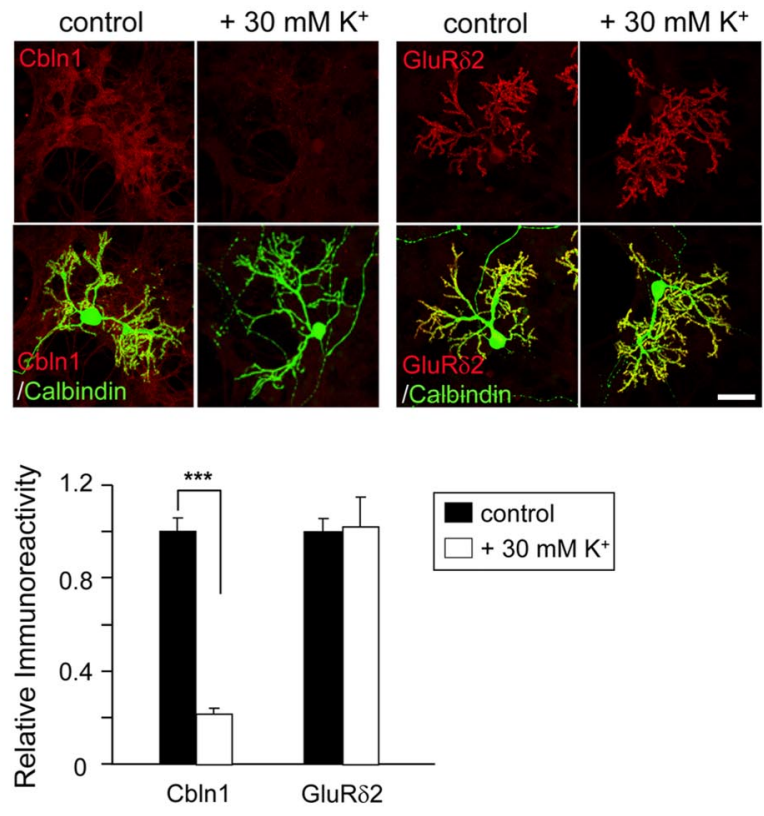

Figure 4. Increased neuronal activity reduced the expression of $\mathrm{Cb} \ln 1$ proteins in granule cells. $\boldsymbol{A}$, High- $\mathrm{K}^{+}$-induced reduction of $\mathrm{Cb} \ln 1$ and $\mathrm{Cb} / \mathrm{n} 3$ proteins in granule cells. Mature granule cells maintained in $5 \mathrm{~mm} \mathrm{~K}^{+}$for 2 weeks were treated with $30 \mathrm{~mm} \mathrm{~K}^{+}$for 1 or $2 \mathrm{~d}$, and the cell lysates were subjected to immunoblot analysis using specific antibodies against Cbln1, Cbln3, and actin. $\boldsymbol{B}$, Quantitative analysis of the high- $\mathrm{K}^{+}$-induced reduction of $\mathrm{Cbln} 1$ and $\mathrm{Cbln} 3$ proteins. Band intensities of Cbln1 or Cbln3 were normalized with those of actin, and the value of untreated ( $0 \mathrm{~d}$ ) granule cells was arbitrarily defined as 1.0. $n=3-4$ independent experiments. ${ }^{* *} p<0.01,{ }^{* * *} p<0.001$ (compared with each untreated group). $C$, Reversibility of high- ${ }^{+}{ }^{+}$-induced reduction of Cbln1. Mature granule cells maintained in $5 \mathrm{~mm} \mathrm{~K}^{+}$for 2 weeks were treated with $30 \mathrm{~mm} \mathrm{~K}^{+}$for $6 \mathrm{~h}$. The cell lysates were harvested at $0 \mathrm{~d}$ (untreated) or 1 or $2 \mathrm{~d}$ after treatment and subjected to immunoblot analysis using specific antibodies against Cbln1 and actin. D, Quantitative analysis of data shown in $\boldsymbol{C}$. Band intensities were normalized to those of actin, and the value of untreated granule cells was arbitrarily defined as 1.0. $n=8$ (in 3 independent experiments). $\boldsymbol{E}$, Immunocytochemical analysis of endogenous Cbln1 and GluR $\delta 2$ in mixed cerebellar cultures after high- $K^{+}$

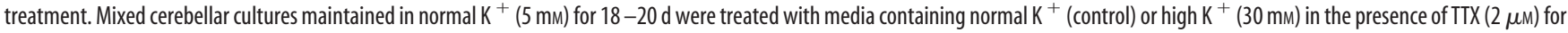
$4 \mathrm{~d}$. Cells were fixed and immunostained using an anti-Cbln1 antibody (red; left), an anti-GluR $\delta 2$ antibody (red; right), or an anti-calbindin antibody (green). Scale bar, $50 \mu m$. $\boldsymbol{F}, 0$ uantitative analysis of the changes in Cbln1 and GluR $\delta 2$ proteins in mixed cerebellar cultures. The fluorescence intensity of Cbln 1 or GluR $\delta 2$ immunoreactivities was measured on the dendrites of Purkinje cell dendrites, which were identified by calbindin immunoreactivity. The mean fluorescence intensity of Cbln1 or GluR $\delta 2$ was normalized to that of calbindin, and the value of control cultures was arbitrarily defined as $1.0 . n=4-5$ independent experiments. ${ }^{* * *} p<0.001$.

change at $6 \mathrm{~h}$ after treatment (supplemental Fig. S2, available at www.jneurosci.org as supplemental material). Furthermore, the inhibitory effect of $60 \mathrm{~mm} \mathrm{~K}{ }^{+}$, which was expected to depolarize neurons to approximately $-24 \mathrm{mV}$, on $c b \ln 1 \mathrm{mRNA}$ expression became evident only after incubation for $1 \mathrm{~h}$ (supplemental Fig. S3, available at www.jneurosci.org as supplemental material). Thus, continuous depolarization lasting for at least an hour was necessary to reduce the $c b \ln 1$ or $c b \ln 3$ mRNA expression levels.

When granule cells were treated with $30 \mathrm{mM} \mathrm{K}^{+}$for $6 \mathrm{~h}$ and then returned to normal solutions, it took $2 \mathrm{~d}$ before the original levels of $c b \ln 1$ and $c b \ln 3$ mRNAs were re-expressed (Fig. 2 E, F). Thus, repression may have lasted for a prolonged period even after the cells had been returned to normal extracellular solutions; alternatively, the expression of $c b \ln 1$ and $c b \ln 3$ mRNAs may simply be a slow process. In contrast, when neuronal activities were blocked by addition of an AMPA receptor antagonist CNQX $(50 \mu \mathrm{M})$ or an NMDA receptor antagonist D-AP5 $(100 \mu \mathrm{M})$ for $1 \mathrm{~d}, c b \ln 1 \mathrm{mRNA}$ expression did not significantly increase (supplemental Fig. $\mathrm{S} 4 A, B$, available at www. jneurosci.org as supplemental material). Similarly, $c b \ln 1$ mRNA expression was not affected by addition of TTX $(2 \mu \mathrm{M})$ or a combination of TTX, CNQX, and D-AP5 (supplemental Fig. S4C,D, available at www.jneurosci.org as supplemental material). Together, these findings indicate that granule cells are equipped with a mechanism to downregulate the expressions of $c b \ln 1$ and $c b \ln 3$ mRNAs in a reversible manner by sensing certain degrees of depolarization that last for an hour or longer.

\section{L-VGCC and CaN mediate high- $\mathrm{K}^{+}$-induced repression of cbln1 mRNA}

To obtain clues to the molecular mechanisms by which high $\mathrm{K}^{+}$ reduced the expression of $c b \ln 1$ and $c b \ln 3$ mRNAs, the involvement of VGCC was examined using a general VGCC blocker, $\mathrm{Cd}^{2+}$. The coapplication of $\mathrm{Cd}^{2+}(10 \mu \mathrm{M})$ significantly blocked the $\mathrm{K}^{+}$-mediated repression of $c b \ln 1$ and $c b \ln 3$ mRNA expression (Fig. $3 A, C$ ). In contrast, the $\mathrm{K}^{+}$-mediated reduction of $c b \ln 1$ and $c b \ln 3$ mRNAs was insensitive to an AMPA receptor antagonist NBQX $(25 \mu \mathrm{M})$ or D-AP5 $(100 \mu \mathrm{M})$, indicating that VGCC is directly activated by membrane depolarization. The inhibitory effect of high $\mathrm{K}^{+}$on $c b \ln 1$ and $c b \ln 3$ mRNA expression was significantly blocked by an L-VGCC inhibitor, nimodipine $(50 \mu \mathrm{M})$. Furthermore, FK520 $(0.5 \mu \mathrm{g} / \mathrm{ml})$, an analog of the specific CaN inhibitor FK506, significantly attenuated the high-K ${ }^{+}-$ evoked repression of $c b \ln 1 \mathrm{mRNA}$, whereas it did not affect the high- $\mathrm{K}^{+}$-evoked repression of $c b \ln 3$ mRNA (Fig. $3 B, C$ ). Addition of FK506 to nimodipine did not further rescue the high- $\mathrm{K}^{+}$evoked repression of $c b \ln 1$ mRNA ( $p=0.79$ ) (supplemental Fig. S5, available at www.jneurosci.org as supplemental material). These results indicate that the depolarization associated with a high $\mathrm{K}^{+}$level likely caused a $\mathrm{Ca}^{2+}$ influx through L-VGCC, followed by CaN activation, thereby repressing $c b \ln 1$ mRNA expression in mature cerebellar granule cells, whereas L-VGCC activated an unknown pathway(s) to repress $c b \ln 3$ mRNA.

The reduction in mRNA expression could have been caused 
by reduced transcription or mRNA destabilization or both. To evaluate the stability of $c b \ln 1 \mathrm{mRNA}$, granule cells were incubated with a transcription blocker actinomycin D $(40 \mu \mathrm{M})$. The level of $c b \ln 1$ mRNA gradually decreased and reached plateau at $\sim 3 \mathrm{~h}$ after treatment (supplemental Fig. S6, available at www.jneurosci. org as supplemental material). The level of $c b \ln 1$ mRNA in granule cells treated with $30 \mathrm{~mm} \mathrm{~K}^{+}$plus actinomycin $\mathrm{D}$ for $3 \mathrm{~h}$ did not differ from that in cells treated with actinomycin $\mathrm{D}$ alone (Fig. $3 \mathrm{D}, \mathrm{E}$ ), indicating that high- $\mathrm{K}^{+}$treatment did not further destabilize $c b \ln 1$ mRNA. Therefore, the expression of $c b \ln 1 \mathrm{mRNA}$ was likely regulated, at least in part, at the transcriptional level.

\section{High $\mathrm{K}^{+}$reduced expression of Cbln1 protein}

An immunoblot analysis revealed that Cbln 1 and Cbln3 protein levels significantly decreased after $24 \mathrm{~h}$ of treatment with $30 \mathrm{mM} \mathrm{K}^{+}$in cultured granule cells (Fig. $4 A, B$ ). Cbln 1 protein levels also decreased at $1 \mathrm{~d}$ after $6 \mathrm{~h}$ of treatment with 30 $\mathrm{mM} \mathrm{K}^{+}$but returned to its original levels next day (Fig. 4C,D). In addition, nimodipine $(50 \mu \mathrm{M})$ partially but significantly attenuated the high- $\mathrm{K}^{+}$-evoked repression of Cbln 1 protein levels (supplemental Fig. S7 $A, B$, available at www.jneurosci.org as supplemental material). These results are consistent with those observed for mRNA levels (Figs. 2E, F, $3 B, C$ ).

We also examined Cbln1 levels in mixed cerebellar cultures containing both granule and Purkinje cells. As we recently showed that Cbln1 was accumulated at the postsynaptic sites of PF-Purkinje cell synapses (Matsuda et al., 2009; Miura et al., 2009), Cbln1 immunoreactivity was highly enriched at Purkinje cell dendrites, which were immunopositive for the GluR $\delta 2$ (Fig. $4 E, F$ ). In contrast, immunoreactivity for Cbln 1 ( $n=17$ for control, $n=18$ for high $\left.\mathrm{K}^{+}, p<0.0001\right)$, but not for GluR $\delta 2(n=17$ for control, $n=16$ for high $\mathrm{K}^{+}, p=0.30$ ), was significantly decreased in mixed cerebellar cultures treated with high $\mathrm{K}^{+}$(Fig. $4 E, F)$. These results indicate that high $\mathrm{K}^{+}$evoked a reduction in $c b \ln 1$ and $c b \ln 3$ mRNA expression resulting in a reduction of the corresponding proteins.

\section{High- $\mathrm{K}^{+}$-induced repression of Cbln 1 reduced PF synapses on Purkinje cells}

Cbln1 is crucial for the maintenance of excitatory synapses formed between PF and Purkinje cells in mature cerebellum (ItoIshida et al., 2008). To examine whether the high- $\mathrm{K}^{+}$-induced regulation of Cbln 1 protein affected the stability of PF synapses, the density of the excitatory synapses on the Purkinje cells' dendrites was estimated using an immunohistochemical analysis with antibodies against VGluT1 and calbindin, markers for glutamatergic presynaptic terminals and Purkinje cells, respectively, in mixed cultures. Treatment with $30 \mathrm{mM} \mathrm{K}^{+}$significantly reduced VGluT1 immunoreactivity on the Purkinje cell dendrites (Fig. $5 A$; enlarged views in $B$, summarized in $C$ ) after $2 \mathrm{~d}$ (control, $n=20$; high $\left.\mathrm{K}^{+}, n=21 ; p<0.001\right)$ and $4 \mathrm{~d}$ (control, $n=37$; high $\left.\mathrm{K}^{+}, n=38 ; p<0.0001\right)$. In contrast, high- $\mathrm{K}^{+}$treatment did not affect immunoreactivity against VGAT, a marker for inhibitory synapses, on Purkinje cell dendrites (control, $n=25$; high $\mathrm{K}^{+}$, $n=25 ; p=0.94$ ) (supplemental Fig. S8, available at www. jneurosci.org as supplemental material). Therefore, treatment with $30 \mathrm{mM} \mathrm{K}^{+}$specifically reduced the number of excitatory synapses on Purkinje cells.

To further establish the causal relationship between the depolarization-induced reduction of Cbln 1 protein levels and the loss of synapses, we next examined whether the addition of exogenous Cbln 1 to the culture medium could rescue the $\mathrm{K}^{+}$-induced loss of excitatory synapses. As reported previously (Ito-Ishida et al., 2008), the application of exogenous Cbln $1(2 \mu \mathrm{g} / \mathrm{ml}, \sim 8.8$ nM) had no effects on VGluT1 immunoreactivity on wild-type Purkinje cells $(n=20 ; p=0.81)$. In contrast, the high- $\mathrm{K}^{+}$induced reduction of VGluT1 immunoreactivity in wild-type Purkinje cells was partially but significantly rescued by the coapplication of exogenous Cbln1 $(n=32 ; p<0.001)$ (Fig. 5A, D). Similarly, the coapplication of nimodipine $(50 \mu \mathrm{M})$ partially ( $p=0.01$ vs control) but significantly inhibited the reduction $\left(n=25 ; p<0.0001\right.$ vs $30 \mathrm{~mm} \mathrm{~K}^{+}$alone) (Fig. $\left.5 A, D\right)$. In contrast, the coapplication of mutant Cbln $1(2 \mu \mathrm{g} / \mathrm{ml})$, in which the $\mathrm{N}$ terminal two cysteine residues were replaced with serine (dSCbln 1) to disrupt binding of Cbln 1 to Purkinje cells (Matsuda et al., 2009), failed to rescue VGluT1 immunoreactivity in $\mathrm{K}^{+}$treated Purkinje cells $(n=17 ; p=0.46)$ (Fig. $5 D)$. The rescuing effect of nimodipine was more prominent than that of Cbln 1 


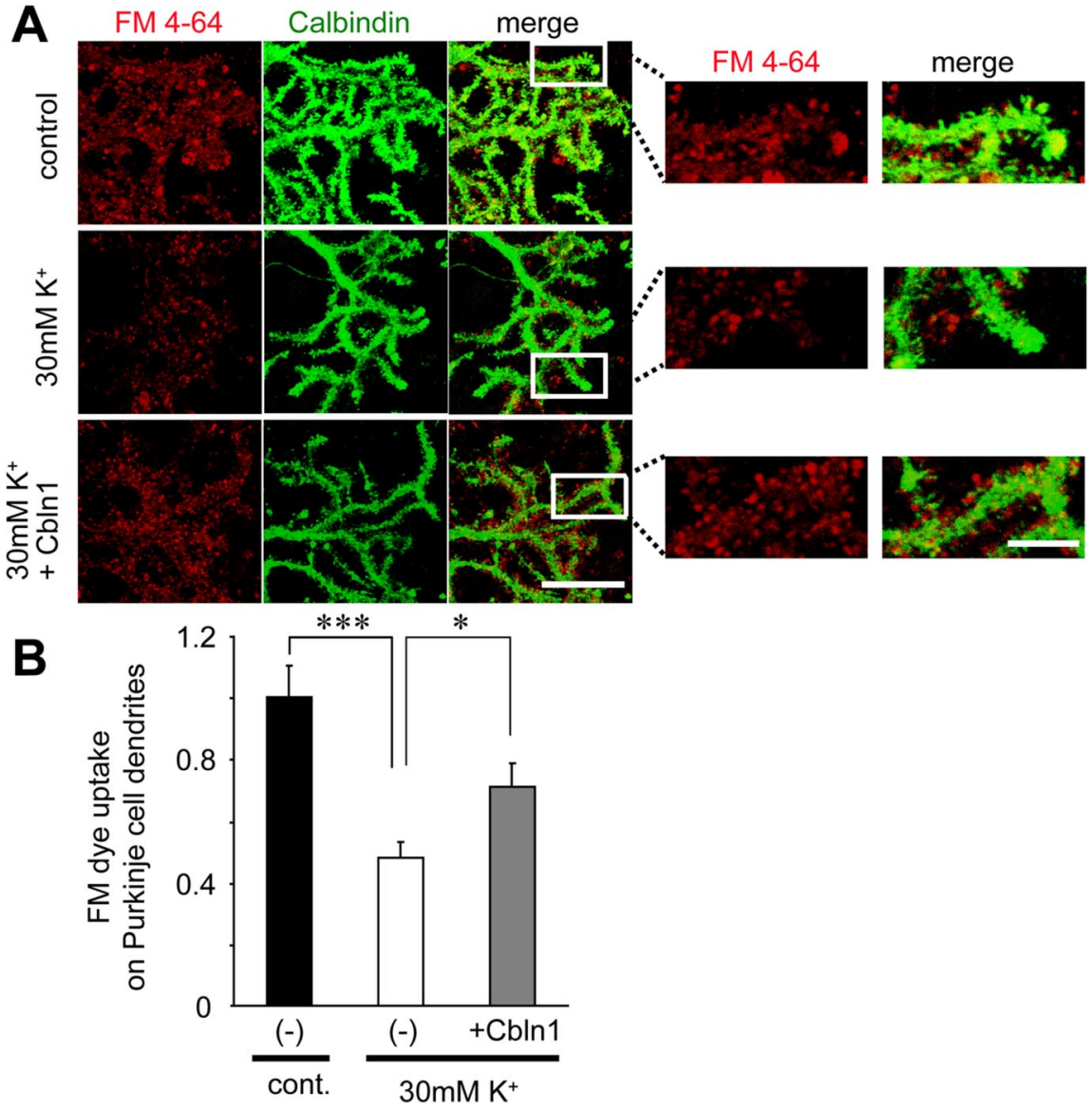

Figure 6. Increased neuronal activity reduced functional presynaptic terminals on Purkinje cells. $\boldsymbol{A}_{,}$High- $\mathrm{K}^{+}$-induced reduction in presynaptic terminals labeled with FM4-64. Mixed cerebellar cultures maintained in normal $\mathrm{K}^{+}(5 \mathrm{~mm})$ for $18-20 \mathrm{~d}$ were treated with media containing normal $\mathrm{K}^{+}$(control), high $\mathrm{K}^{+}(30 \mathrm{~mm})$, and high $\mathrm{K}^{+}$plus exogenous Cbln 1 ( $\left.2 \mu \mathrm{g} / \mathrm{ml}\right)$ for $3 \mathrm{~d}$. The functional presynaptic terminals were labeled with FM4-64 (red) as described in Materials and Methods. Cells were subsequently fixed and immunostained for calbindin (green), a marker for Purkinje cells. The right panels indicate enlarged images of the Purkinje cell dendrites shown in white boxes in left panels. Scale bars: left, $20 \mu \mathrm{m}$; right, $5 \mu \mathrm{m}$. $\boldsymbol{B}$, Quantitative analysis of the presynaptic marker FM4-64 on Purkinje cells after control (5 mm; cont.) or high- $\mathrm{K}^{+}(30 \mathrm{~mm})$ treatment together with none (-) or exogenous Cbln1 (2 $\mu \mathrm{g} / \mathrm{ml})$ for $3 \mathrm{~d}$. Exogenous Cbln1 significantly rescued the reduced presynaptic terminals labeled with FM4-64 seen on high- $K^{+}$-treated Purkinje cell dendrites. $n=18$ neurons each from three independent experiments. ${ }^{*} p<0.05$, *** $p<0.001$.

$(n=25 ; p=0.006)$ (Fig. $5 A, D)$; however, the coapplication of Cbln 1 and nimodipine did not further rescue VGluT1 immunoreactivity in $\mathrm{K}^{+}$-treated Purkinje cells $(n=16$; nimodipine vs nimodipine plus Cbln $1 ; p=0.63)$. These results indicate that activation of L-VGCC and the reduction of Cbln 1 at least partly share the common signaling pathway and responsible for the high- $\mathrm{K}^{+}$induced decrease in excitatory synapses on Purkinje cells.

Finally, we examined whether the activity-induced reduction in VGluT1 immunoreactivity indeed reflected changes in functional synapses. Application of Cbln 1 was previously shown to rapidly increase functional PF synapses, as evidenced by increased frequency of miniature EPSCs (mEPSCs) recorded in immature (postnatal day 9-12) $c b \ln 1^{-1-}$ Purkinje cells (ItoIshida et al., 2008). However, since mature (18-20 DIV) wildtype cerebellar cultures needed to be used in this study, it was very difficult to analyze mEPSCs reliably because of the variable and uncontrollable electrotonic distances of Purkinje cells' dendrites. Thus, we examined the functions of PF synapses by uptake of the fluorescent styryl dye FM4-64 into presynaptic vesicles. Treatment with $30 \mathrm{mM} \mathrm{K}^{+}$for 3 d significantly reduced the FM4-64 fluorescence on the Purkinje cell dendrites (Fig. 6A,B) (control, $\left.n=18 ; 30 \mathrm{~mm} \mathrm{~K}^{+}, n=18 ; p=0.0002\right)$. Furthermore, the high- $\mathrm{K}^{+}$-induced reduction of the FM4-64 fluorescence on the Purkinje cell dendrites was partially but significantly rescued by the coapplication of exogenous Cbln1 $(2 \mu \mathrm{g} / \mathrm{ml})$ (Fig. $6 A, B)$ $(n=18 ; p=0.016)$. Together, these results indicate that the activity-induced downregulation of Cbln 1 protein (Fig. 4) reduced immunohistochemical (VGluT1 immunoreactivity) (Fig. 5) and functional (FM4-64 uptake) (Fig. 6) synapses on Purkinje cells.

\section{Depolarization blocked the expression of $c b \ln 1$ mRNA in developing granule cells}

We previously showed that the expressions of $c b \ln 1$ and $c b \ln 3$ mRNAs increased during the postnatal period (Miura et al., 2006). Interestingly, the resting membrane potential of granule cells progressively declines during normal development (Rossi et al., 1998; Nakanishi and Okazawa, 2006). To examine whether the expressions of $c b \ln 1$ and $c b \ln 3 \mathrm{mRNAs}$ are also regulated by membrane potentials, we maintained granule cells in a culture media containing 5 or $30 \mathrm{mM} \mathrm{K}^{+}$from 0 to 14 DIV (Fig. 6A). The expression of $c b \ln 1$ and $c b \ln 3$ mRNAs was significantly prevented in granule cells maintained in the medium containing $30 \mathrm{mM} \mathrm{K}^{+}$(Fig. 6B,C). Treatment with nimodipine $(50 \mu \mathrm{M})$ or FK520 $(0.5 \mu \mathrm{g} / \mathrm{ml})$ for the last $3 \mathrm{~d}$ completely rescued the expression of $c b \ln 1 \mathrm{mRNA}$ and partially rescued $c b l n 3$ mRNA expression (Fig. $6 B, C)$. In contrast, NBQX $(25 \mu \mathrm{M})$ or D-AP5 $(100 \mu \mathrm{M})$ did not rescue the expression of $c b \ln 1$ and $c b \ln 3$ mRNAs. Similarly, Cbln1 protein levels significantly decreased in granule cells maintained in the medium containing $30 \mathrm{mM} \mathrm{K}{ }^{+} ; 3 \mathrm{~d}$ treatment with nimodipine $(50 \mu \mathrm{M})$ or FK520 $(0.5 \mu \mathrm{g} / \mathrm{ml})$, but not D-AP5 $(100 \mu \mathrm{M})$, rescued the expression of Cbln 1 protein (supplemental Fig. $\mathrm{S} 7 C, D$, available at www.jneurosci.org as supplemental material). These results were similar to those obtained from mature granule cells transiently treated with high $\mathrm{K}^{+}$(Fig. 3). Similarly, the expression of $G A B A_{A} \alpha 6$ mRNA, which normally occurs specifically in mature granule cells in the IGL, was prevented by maintaining the granule cells in media containing $30 \mathrm{~mm} \mathrm{~K}^{+}$(Fig. 6B,C), a result that was consistent with an earlier report (Mellor et al. 1998). Treatment with nimodipine or FK520 for the last $3 \mathrm{~d}$ also partially rescued $G A B A_{A} \alpha 6$ mRNA expression (Fig. $6 B, C$ ). Nevertheless, unlike the expression of $c b \ln 1 \mathrm{mRNA}$, the expression of $G A B A_{A} \alpha 6$ mRNA was not repressed by transient high- $\mathrm{K}^{+}$treatment in mature granule cells (Fig. $6 \mathrm{D}$ ). Although NR2C mRNA is selectively expressed in mature granule cells in the IGL (Suzuki et al., 2005), its expression was not suppressed in granule cells maintained in high $\mathrm{K}^{+}$under our current experimental conditions (Fig. 6B). These results indicate that the developmental expression of $c b \ln 1$ and $c b \ln 3$ mRNAs may be regulated by changes in membrane potential in the IGL and the subsequent 
activation of $\mathrm{L}-\mathrm{VGCC}$ and $\mathrm{CaN}$, in a manner similar to that which occurs in mature granule cells; although other genes, such as $N R 2 C$ and $G A B A_{A} \alpha 6$, are specifically expressed in mature granule cells in the IGL, their regulatory mechanisms may be distinct from those for $c b \ln 1$ and $c b \ln 3$.

\section{Discussion}

Activity-dependent regulation of $c b \ln 1$ as homeostatic synaptic plasticity

We have shown recently that Cbln 1 is essential for the maintenance of excitatory synapses between PF and Purkinje cells both in vitro and in vivo; the loss of exogenous Cbln 1 resulted in the gradual loss of PF synapses within a few weeks in mature $c b \ln 1^{-1-}$ cerebellum (Ito-Ishida et al., 2008). Here, we show that the expression of $c b \ln 1$ mRNA was downregulated by the chronic stimulation of neuronal activity arising from an elevation in extracellular $\mathrm{K}^{+}$ levels in mature granule cells (Figs. 1, 2). Subsequently, chronic high- $\mathrm{K}^{+}$treatment decreased Cbln1 protein levels (Fig. 4) and the number of excitatory synapses on Purkinje cell dendrites in culture (Figs. 5, 6). These results indicate that the activitydependent downregulation of $c b \ln 1$ may serve as a mechanism by which cerebellar granule cells adapt to chronically elevated activity, thereby maintaining homeostasis.

Synaptic homeostasis is induced by chronic neuronal activity lasting for hours to days to ensure that neurons continually operate within a dynamic physiological range of activity (Burrone and Murthy, 2003; Turrigiano and Nelson, 2004). Such adaptive changes are thought to normalize overall neuronal activity after classical synapse-specific Hebbian plasticities, such as long-term potentiation and long-term depression, or after aberrant excitation (such as seizures). Although there has been some progress in understanding the homeostatic response to chronic inactivity, little is known about the molecular mechanisms that mediate the adaptation to chronically elevated activity. Recently, Polo-like kinase 2 (Plk2) has been shown to be upregulated after a chronic elevation of activity in hippocampal neurons; Plk2 reduces postsynaptic responses by preventing activity-induced morphological changes at the spines and by reducing membrane excitability (Seeburg and Sheng, 2008). Thus, Cbln1 may serve as another mechanism responsible for adaptation to increased neuronal activity in the cerebellum; however, unlike Plk2, Cbln1 works through presynaptic mechanism. In addition, unlike several other presynaptic homeostatic mechanisms, Cbln1 did not respond to chronic inactivity (supplemental Fig. S7, available at www.jneurosci.org as supplemental material).

Like $c b \ln 1, c b \ln 3$ mRNA and its protein level were both downregulated by the chronic neuronal activity induced by high $\mathrm{K}^{+}$in granule cells (Figs. 1-4). Although the precise role of Cbln3 in vivo remains unclear, one of its putative functions is the negative regulation of the release of Cbln1 through the formation of Cbln1-Cbln3 heteromers, which are mostly retained in the soma (Iijima et al., 2007). Interestingly, the high- $\mathrm{K}^{+}$-induced repres- sion of $c b \ln 3$ mRNA was slightly but significantly delayed by that of $c b \ln 1$ mRNA (Fig. $2 C-F$ ). Thus, the increased ratio of Cbln 3 to Cbln 1 during the early phase of elevated neuronal activity may serve to reduce the amount of secreted Cbln1, supplementing downregulation at the transcriptional level.

\section{Developmental upregulation of $\operatorname{cbln} 1$ expression in the IGL}

The resting membrane potential of many types of immature neurons, such as the lateral geniculate nucleus relay neurons (Ramoa and McCormick, 1994), layer I cortical neurons (Zhou and Hablitz, 1996), and CA3 granule neurons (Tyzio et al., 2003), has been shown to be relatively depolarized, compared with that of mature neurons. In the cerebellum, the resting membrane potential of granule cells progressively declines during postnatal development, from approximately $-24 \mathrm{mV}$ (immature granule cells in the EGL) to $-58 \mathrm{mV}$ (mature granule cells in the IGL) (Rossi et al., 1998). The genome-wide expression profiles of granule cells maintained in $25 \mathrm{mM} \mathrm{K}^{+}$have indicated that depolarization induces many genes that are normally expressed in immature granule cells in the EGL and have been implicated in cell proliferation, migration, and neurite growth (Sato et al., 2005). In contrast, depolarization downregulated genes encoding synapse-related molecules, such as NR2C (Suzuki et al., 2005), GABA $\alpha 6$ (Mellor et al., 1998), and cannabinoid receptor CB1 (Vallano et al., 2006); these genes are found in differentiated granule cells in the IGL (Sato et al., 2005). Here, we showed that the continuous depolarization of granule cells during development repressed the expressions of $c b \ln 1$ and $c b \ln 3$ mRNAs (Fig. 7), adding to the list of 


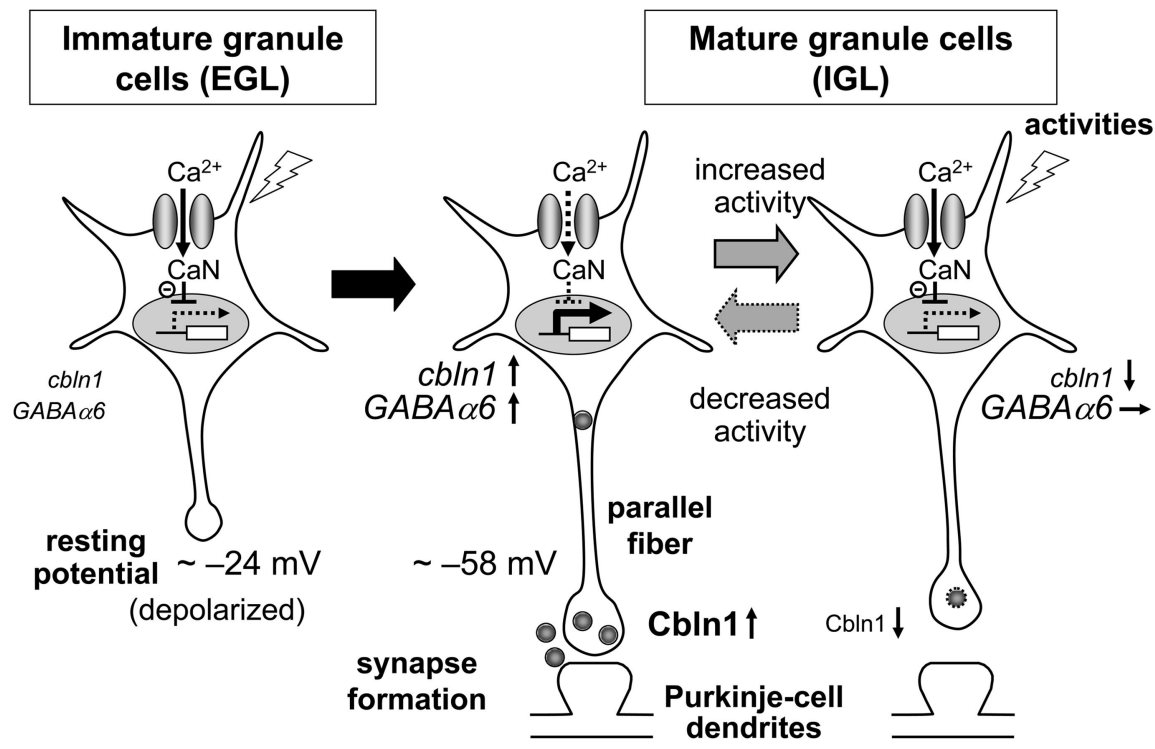

Figure 8. A model for the activity-dependent regulation of cbln1. In immature granule cells in the EGL, the resting membrane potentials are depolarized because of high extracellular $\mathrm{K}^{+}$concentrations. Thus, $\mathrm{Ca}^{2+}$ influx through L-VGCC activates CaN and inhibits the expression of $c b / n 1 \mathrm{mRNA}$. In mature granule cells in the IGL, the resting membrane potentials are repolarized, leading to the removal of the CaN-dependent repression of $c$ ln 1 mRNA expression. Together with other developmentally upregulated genes, such as $G A B A \alpha 6$, increased cbln 1 may mediate synaptogenesis between parallel fibers and Purkinje cell dendrites. When neuronal activities are chronically increased in mature granule cells, $\mathrm{Ca}^{2+}$ influx through L-VGCC again activates CaN and downregulates the expression of $c b \ln 1 \mathrm{mRNA}$, but not GABA $\alpha 6 \mathrm{mRNA}$, leading to the loss of parallel fiber-Purkinje cell synapses. This activity-dependent downregulation of cbln 1 may serve as a presynaptic mechanism by which PF-Purkinje cell synapses adapt to chronically elevated activity levels, thereby maintaining homeostasis.

depolarization-downregulated genes. Since Cbln1 is a strong synapse-organizing protein, it makes perfect sense that the expression of $c b \ln 1$ mRNA is controlled by membrane potential during development (Fig. 8).

CaN-dependent downregulation of $c b \ln 1 \mathrm{mRNA}$ expression $\mathrm{Ca}^{2+}$ signaling plays a key role in eliciting neuronal activitydependent transcription. Among various $\mathrm{Ca}^{2+}$-permeable channels, L-VGCCs are particularly effective at activating transcription factors (Bading et al., 1993), such as cAMP response element-binding protein, myocyte enchnacer factor 2 (MEF2), and nuclear factor of activated T cells (NFAT) (Sheng et al., 1990; Graef et al., 1999; Mao et al., 1999), leading to the expression of genes such as $c$-fos and BDNF (Zafra et al., 1990; West et al., 2002). MEF2 (Flavell et al., 2006; Shalizi et al., 2006) and NFAT (Rao et al., 1997; Rana et al., 2008) are both activated by $\mathrm{Ca}^{2+}$ / calmodulin-dependent CaN. Similarly, the expression of $c b \ln 1$ and $c b \ln 3$ depended on L-VGCC and CaN; however, it was repressed, rather than activated, by CaN. Indeed, although the emphasis of earlier studies was on how $\mathrm{Ca}^{2+}$ signaling enhances transcription, a recent genome-wide expression study has indicated that $\mathrm{Ca}^{2+}$ and CaN not only upregulate but also downregulate various genes in cerebellar granule cells (Sato et al., 2005). The finding that the depolarization-induced loss of synapses on Purkinje cells was only partially rescued by exogenous Cbln1 (Fig. 5 ) also suggests that other genes downregulated by $\mathrm{Ca}^{2+}$ may be involved in this phenomenon. Nevertheless, little is known about how $\mathrm{Ca}^{2+}$ and $\mathrm{CaN}$ mediate transcriptional repression. Recently, $\mathrm{CaN}$-activated NFAT has been shown to function as a transcriptional repressor of fast contractile genes after increased chronic activity in slow muscles, probably by forming a complex with certain nuclear factors (Rana et al., 2008). Further studies are necessary to understand the molecular mechanisms by which
$\mathrm{CaN}$ represses a certain population of genes, including $c b \ln 1$ and $c l b n 3$.

Although a CaN inhibitor, FK520, significantly attenuated the high- $\mathrm{K}^{+}$-evoked repression of $c b \ln 1 \mathrm{mRNA}$, it did not affect the repression of $c b \ln 3$ mRNA (Fig. 3C). Similarly, although FK520 almost completely rescued the expression of $c b \ln 1$ in immature granule cells cultured in high $\mathrm{K}^{+}$, it had a small effect on $c b \ln 3$ mRNA (Fig. 7C). Thus, a CaN-independent pathway also likely mediates, at least in part, the high- $\mathrm{K}^{+}$-dependent repression of the expression of $c b \ln 1$ and, particularly, $c b \ln 3$. For example, elevated intracellular $\mathrm{Ca}^{2+}$ has been recently shown to decrease the amount of the C-terminal fragment of L-VGCC, which can serve as a transcriptional activator or repressor (GomezOspina et al., 2006). Furthermore, not only FK520 but also nimodipine could not completely rescue the repression of the expression of $c b \ln 3$ in immature granule cells cultured in high $\mathrm{K}^{+}$(Fig. 7C), suggesting the presence of a pathway that does not rely on L-VDCC to regulate $c b \ln 3$ expression. Similarly, the depolarizationinduced repression of $G A B A_{A} \alpha 6$ expression was relatively insensitive to nimodipine in immature granule cells (Fig. 7C), as reported earlier (Mellor et al., 1998). These findings indicate that the depolarization-induced repression of gene expression can be mediated by several pathways in addition to those that depend on L-VGCC and CaN.

\section{Physiological role of activity-induced downregulation of $c b \ln 1$}

The $c b \ln 1$ mRNA remains highly expressed in adult cerebellum (Miura et al., 2006) and did not respond to chronic neuronal inactivity (supplemental Fig. S4, available at www.jneurosci.org as supplemental material). In addition, application of exogenous Cbln 1 failed to induce any synaptogenesis in wild-type cerebellum (Ito-Ishida et al., 2008). Thus, PF-Purkinje cell synapses are likely saturated and stabilized by endogenous Cbln 1 in wild-type adult cerebellum. Nevertheless, changes in neuronal activity reportedly induce considerable structural changes at PF synapses in adult cerebellum in vivo (Black et al., 1990; Cesa et al., 2007). Therefore, we speculate that the activity-induced repression of cbln1 mRNA described here may serve as a mechanism to allow such structural changes to occur at mature PF synapses. Further studies are warranted to clarify the role of Cbln 1 in the regulation of activity-dependent structural plasticity in adult wild-type cerebellum. Since the Cbln family (Cbln1-Cbln4) and other C1q/ TNF $\alpha$ superfamily members are expressed in various regions of the mature brain (Yuzaki, 2008), understanding the role of Cbln 1 will be of great benefit for unraveling various forms of synaptic plasticity in the adult brain.

\section{References}

Bading H, Ginty DD, Greenberg ME (1993) Regulation of gene expression in hippocampal neurons by distinct calcium signaling pathways. Science 260:181-186.

Bao D, Pang Z, Morgan JI (2005) The structure and proteolytic processing of Cbln1 complexes. J Neurochem 95:618-629. 
Bessho Y, Nakanishi S, Nawa H (1993) Glutamate receptor agonists enhance the expression of BDNF mRNA in cultured cerebellar granule cells. Brain Res Mol Brain Res 18:201-208.

Bessho Y, Nawa H, Nakanishi S (1994) Selective up-regulation of an NMDA receptor subunit mRNA in cultured cerebellar granule cells by $\mathrm{K}(+)$ induced depolarization and NMDA treatment. Neuron 12:87-95.

Black JE, Isaacs KR, Anderson BJ, Alcantara AA, Greenough WT (1990) Learning causes synaptogenesis, whereas motor activity causes angiogenesis, in cerebellar cortex of adult rats. Proc Natl Acad Sci U S A 87:5568-5572.

Burrone J, Murthy VN (2003) Synaptic gain control and homeostasis. Curr Opin Neurobiol 13:560-567.

Cesa R, Scelfo B, Strata P (2007) Activity-dependent presynaptic and postsynaptic structural plasticity in the mature cerebellum. J Neurosci 27:4603-4611.

Flavell SW, Cowan CW, Kim TK, Greer PL, Lin Y, Paradis S, Griffith EC, Hu LS, Chen C, Greenberg ME (2006) Activity-dependent regulation of MEF2 transcription factors suppresses excitatory synapse number. Science 311:1008-1012.

Gomez-Ospina N, Tsuruta F, Barreto-Chang O, Hu L, Dolmetsch R (2006) The $\mathrm{C}$ terminus of the L-type voltage-gated calcium channel $\mathrm{Ca}(\mathrm{V}) 1.2$ encodes a transcription factor. Cell 127:591-606.

Graef IA, Mermelstein PG, Stankunas K, Neilson JR, Deisseroth K, Tsien RW, Crabtree GR (1999) L-type calcium channels and GSK-3 regulate the activity of NF-ATc4 in hippocampal neurons. Nature 401:703-708.

Hirai H, Pang Z, Bao D, Miyazaki T, Li L, Miura E, Parris J, Rong Y, Watanabe M, Yuzaki M, Morgan JI (2005) Cbln1 is essential for synaptic integrity and plasticity in the cerebellum. Nat Neurosci 8:1534-1541.

Iijima T, Miura E, Matsuda K, Kamekawa Y, Watanabe M, Yuzaki M (2007) Characterization of a transneuronal cytokine family Cbln-regulation of secretion by heteromeric assembly. Eur J Neurosci 25:1049-1057.

Ito-Ishida A, Miura E, Emi K, Matsuda K, Iijima T, Kondo T, Kohda K, Watanabe M, Yuzaki M (2008) Cbln1 regulates rapid formation and maintenance of excitatory synapses in mature cerebellar Purkinje cells in vitro and in vivo. J Neurosci 28:5920-5930.

Kurschner C, Yuzaki M (1999) Neuronal interleukin-16 (NIL-16): a dual function PDZ domain protein. J Neurosci 19:7770-7780.

Mao Z, Bonni A, Xia F, Nadal-Vicens M, Greenberg ME (1999) Neuronal activity-dependent cell survival mediated by transcription factor MEF2. Science 286:785-790.

Matsuda K, Kondo T, Iijima T, Matsuda S, Watanabe M, Yuzaki M (2009) Cbln1 binds to specific postsynaptic sites at parallel fiber-Purkinje cell synapses in the cerebellum. Eur J Neurosci 29:707-717.

Mellor JR, Merlo D, Jones A, Wisden W, Randall AD (1998) Mouse cerebellar granule cell differentiation: electrical activity regulates the $\mathrm{GABA}_{\mathrm{A}}$ receptor $\alpha 6$ subunit gene. J Neurosci 18:2822-2833.

Miura E, Iijima T, Yuzaki M, Watanabe M (2006) Distinct expression of Cbln family mRNAs in developing and adult mouse brains. Eur J Neurosci 24:750-760.

Miura E, Matsuda K, Morgan JI, Yuzaki M, Watanabe M (2009) Cbln1 accumulates and colocalizes with $\mathrm{Cbln} 3$ and $\operatorname{GluR} \delta 2$ at parallel fiber-
Purkinje cell synapses in the mouse cerebellum. Eur J Neurosci 29:693-706.

Miyazaki T, Fukaya M, Shimizu H, Watanabe M (2003) Subtype switching of vesicular glutamate transporters at parallel fibre-Purkinje cell synapses in developing mouse cerebellum. Eur J Neurosci 17:2563-2572.

Nakanishi S, Okazawa M (2006) Membrane potential-regulated Ca2 + signalling in development and maturation of mammalian cerebellar granule cells. J Physiol 575:389-395.

Ramoa AS, McCormick DA (1994) Developmental changes in electrophysiological properties of LGNd neurons during reorganization of retinogeniculate connections. J Neurosci 14:2089-2097.

Rana ZA, Gundersen K, Buonanno A (2008) Activity-dependent repression of muscle genes by NFAT. Proc Natl Acad Sci U S A 105:5921-5926.

Rao A, Luo C, Hogan PG (1997) Transcription factors of the NFAT family: regulation and function. Annu Rev Immunol 15:707-747.

Rossi P, De Filippi G, Armano S, Taglietti V, D’Angelo E (1998) The weaver mutation causes a loss of inward rectifier current regulation in premigratory granule cells of the mouse cerebellum. J Neurosci 18:3537-3547.

Sato M, Suzuki K, Yamazaki H, Nakanishi S (2005) A pivotal role of calcineurin signaling in development and maturation of postnatal cerebellar granule cells. Proc Natl Acad Sci U S A 102:5874-5879.

Seeburg DP, Sheng M (2008) Activity-induced Polo-like kinase 2 is required for homeostatic plasticity of hippocampal neurons during epileptiform activity. J Neurosci 28:6583-6591.

Shalizi A, Gaudillière B, Yuan Z, Stegmüller J, Shirogane T, Ge Q, Tan Y, Schulman B, Harper JW, Bonni A (2006) A calcium-regulated MEF2 sumoylation switch controls postsynaptic differentiation. Science 311:1012-1017.

Sheng M, McFadden G, Greenberg ME (1990) Membrane depolarization and calcium induce c-fos transcription via phosphorylation of transcription factor CREB. Neuron 4:571-582.

Suzuki K, Sato M, Morishima Y, Nakanishi S (2005) Neuronal depolarization controls brain-derived neurotrophic factor-induced upregulation of NR2C NMDA receptor via calcineurin signaling. J Neurosci 25:9535-9543.

Turrigiano GG, Nelson SB (2004) Homeostatic plasticity in the developing nervous system. Nat Rev Neurosci 5:97-107.

Tyzio R, Ivanov A, Bernard C, Holmes GL, Ben-Ari Y, Khazipov R (2003) Membrane potential of CA3 hippocampal pyramidal cells during postnatal development. J Neurophysiol 90:2964-2972.

Vallano ML, Beaman-Hall CM, Bui CJ, Middleton FA (2006) Depolarization and $\mathrm{Ca}(2+)$ down regulate $\mathrm{CB} 1$ receptors and $\mathrm{CB} 1$-mediated signaling in cerebellar granule neurons. Neuropharmacology 50:651-660.

West AE, Griffith EC, Greenberg ME (2002) Regulation of transcription factors by neuronal activity. Nat Rev Neurosci 3:921-931.

Yuzaki M (2008) Cbln and C1q family proteins: new transneuronal cytokines. Cell Mol Life Sci 65:1698-1705.

Zafra F, Hengerer B, Leibrock J, Thoenen H, Lindholm D (1990) Activity dependent regulation of BDNF and NGF mRNAs in the rat hippocampus is mediated by non-NMDA glutamate receptors. EMBO J 9:3545-3550.

Zhou FM, Hablitz JJ (1996) Postnatal development of membrane properties of layer I neurons in rat neocortex. J Neurosci 16:1131-1139. 